\title{
Stress in Broiler Chickens Due to Acute Noise Exposure
}

\author{
Petr Chloupek ${ }^{1}$, Eva Voslářová ${ }^{1}$, Jan Chloupek², Iveta Bedáňová1, \\ Vladimíra Pištěková ${ }^{\text {, Vladimír Večerek }}{ }^{1}$ \\ ${ }^{1}$ Department of Veterinary Public Health and Toxicology, ${ }^{2}$ Department of Nutrition, Livestock Breeding \\ and Animal Hygiene, Faculty of Veterinary Hygiene and Ecology, \\ University of Veterinary and Pharmaceutical Sciences in Brno, Czech Republic
}

Received March 4, 2008

Accepted October 1, 2008

\begin{abstract}
Stress effects from acute noise exposure were monitored in a group of ROSS 308 broiler chickens $(n=80)$, aged 42 days. The experiment simulated slaughterhouse sounds to which the broilers were exposed for $10 \mathrm{~min}$ in the test enclosure. Effects of acute noise exposure at two different levels $(80 \mathrm{~dB}$ and $100 \mathrm{~dB})$ were evaluated on the basis of examinations of selected biochemical plasma indicators and tonic immobility tests. Noise stimuli of both $80 \mathrm{~dB}$ and $100 \mathrm{~dB}$ intensities for $10 \mathrm{~min}$ induced a significant elevation in plasma corticosterone levels. Broilers that were exposed to noise stimuli of $100 \mathrm{~dB}$ also exhibited a significant increase in the cholesterol level and total protein level. Exposure to noise stimuli did not influence the glucose level and triglyceride concentrations. The duration of tonic immobility was not affected by noise stimuli in our experiment. However, noise exposure at a $100 \mathrm{~dB}$ level decreased the number of attempts to induce tonic immobility in broilers.
\end{abstract}

Poultry, sound, slaughter, corticosterone, tonic immobility, welfare

The Protocol on Protection and Welfare of Animals annexed to the Treaty establishing the European Community, requires that in formulating and implementing agriculture policies, the Community and its Member States are to pay full regard to the welfare requirements of animals. The achievement of the basic objective of introducing animal welfare improvements, as well as improvements in the intensive farming of chickens, is necessary and appropriate. In 2007, Council Directive 2007/43/EC laying down minimum rules for the protection of chickens kept for meat production was adopted. Member States shall bring into force the laws, regulations and administrative provisions necessary to comply with this Directive by June 30,2010. In the meantime, it is required to report new scientific evidence taking into account further research and practical experience in order to improve further the welfare of chickens kept for meat production, particularly regarding aspects not covered by this Directive. These reports should specifically consider the possibility of introducing thresholds for indications of poor welfare conditions. Noise exposure in broiler chickens during rearing, transport for slaughter, and before slaughter in slaughterhouses is one of the areas where the legislation has not yet been exactly defined. It is required by the Council Directive 2007/43/EC that the sound level shall be minimised. Ventilation fans, feeding machinery and other equipment shall be constructed, placed, operated and maintained in such a way that causes the least possible amount of noise. However, as is the case with pigs, maximum noise level is not strictly laid down in poultry. Analogously, the Council of Europe Recommendation No. R (91) 7 on the slaughter of animals emphasizes that care should be taken to protect the animals from excessive noise, for example, by avoiding the use of noisy hydraulic or pneumatic equipment, and muffling noisy metal equipment with the use of suitable padding, or by minimising the transmission of such noise to the areas where animals are held and slaughtered.

It is well documented that noise is a stress factor in farm animals (Forsling et al. 1984;

\footnotetext{
Address for correspondence:

Doc. MVDr. Petr Chloupek, Ph.D.

Department of Veterinary Public Health and Toxicology

Faculty of Veterinary Hygiene and Ecology

University of Veterinary and Pharmaceutical Sciences in Brno

Palackého 1-3

61242 Brno, Czech Republic
}

Phone: +420541562777
Fax: +420 541562790
E-mail: chloupekp@vfu.cz
http://www.vfu.cz/acta-vet/actavet.htm 
Stephens et al. 1985; Agnes et al. 1990; Talling et al. 1996; Waynert et al. 1999; Lanier et al. 2000; Schaffer et al. 2001; Otten et al. 2004; Kanitz et al. 2005; De la Fuente et al. 2007). Grandin (1996) and Geverink et al. (1998) pointed out the instances of poor welfare in slaughterhouses due to excessive noise. Noise as a stress factor in poultry has not been investigated thoroughly, although it seems that it can adversely affect the productive performance and behaviour of the birds (Campo et al. 2005). Stadelman (1958a) reported that the sound intensity of $115 \mathrm{~dB}$ was effective in interrupting the brooding of hens. Hamm (1967) found that longer periods of noise-induced stress reduced egg production. To the contrary, McFarlane et al. (1989a) reported that noise did not influence the weight gain, feed intake, or behavioural traits in broiler chickens. Stadelman (1958b) observed violent behavioural response (crowding) to intermittent sound exposure at 100-118 dB in young chickens. Book and Bradley (1990) found panic and aggression in turkeys exposed to noise. The relationship between noise and indicators of stress in poultry was studied by Borg (1981), McFarlane and Curtis (1989), McFarlane et al. (1989b), Gross (1990), Maxwell (1993), Lazarević et al. (2000), and Campo et al. (2005).

Noise also has an important psychological component, and therefore is a potential source of fear in animals. Campo et al. (2005) reported that the tonic immobility duration was significantly longer within a group of hens exposed to noise at a level of $90 \mathrm{~dB}$ for $60 \mathrm{~min}$. Authors found this trait consistent with the heterophil to lymphocyte ratio changes. Birds in the noise treatment groups were frightened by sound, with most of the birds piling up in the corners or laying flat on the floor.

The aim of this present study was to assess the effects of acute noise exposure and the subsequent stress response in broiler chickens. The level of noise in the experiment corresponded to that to which broilers are typically exposed before slaughter, predominantly produced by ventilation fans and operational machinery at slaughterhouses.

\section{Materials and Methods}

Animals and their treatment

Stress effects due to acute noise exposure were monitored in a group of ROSS 308 broiler chickens aged 42 days. From the first day after hatching, a total of 150 broilers was housed in deep litter in 3 aviaries (50 broilers each) in an experimental barn with controlled light, heating, hygienic and feeding patterns according to standard breeding requirements for meat hybrid poultry. The ambient barn temperature was gradually decreased from $30 \pm 1{ }^{\circ} \mathrm{C}$ on Day 1 to $20 \pm 1^{\circ} \mathrm{C}$ on the last day of fattening (Day 42). Depending on the temperature, relative humidity levels ranged between $25 \%$ and $55 \%$. When the broilers were 42 days old, 80 chickens were selected at random for testing. The selected broilers were individually captured and transported by hand to the adjacent test room. Twenty broilers ( 10 males and 10 females) were exposed to a noise level of $80 \mathrm{~dB}$ for $10 \mathrm{~min}$; another 20 broilers (10 males and 10 females) were exposed to a noise level of $100 \mathrm{~dB}$ for $10 \mathrm{~min}$. There were 4 broilers at a time in the test room and the birds could move freely within the room during the test. The birds were exposed to a specific sound stimulus from a tape recording of a mixture of different sounds recorded in the operational plant of a slaughterhouse. The noise from ventilation fans was predominant, and also included was the background noise of the slaughter line and operating carts. To broadcast the sounds, a Boschmann G-9633 S (BM Boschmann, J) with two speakers was hung in the test room. In order to ensure that the results would not be affected by the transfer of broilers to the test room, 20 broilers (10 males and 10 females) were transferred to the test room and allowed to stay there for 10 min in the absence of noise (positive control group). The control group of broilers (10 males and 10 females) was kept undisturbed for the entire period preceding the test. The pre-stress sound level in broiler housing was $55 \mathrm{~dB}$. Noise intensity was measured using the Digital sound meter GSH 8922 (Greisinger, D).

Biochemical examination

A total of 40 birds: 10 birds per test group exposed to $80 \mathrm{~dB}$ (B80), 10 birds per test group exposed to 100 $\mathrm{dB}$ (B100), 10 birds per positive control group (B0) and 10 birds per control group of broilers (B) were used for biochemical examination. Each group of broilers consisted of 5 males and 5 females. Immediately following a 10 min noise exposure of each broiler in the test room (groups B80 and B100) and immediately following 10 min in the test room without noise exposure (group B0), blood samples were withdrawn from the vena basilica in the broilers of each test group and also in the other 10 randomly selected broilers that were kept undisturbed for the entire preceding period. Blood samples were collected within $2 \mathrm{~min}$ of capture in order to ensure that the levels of the monitored indicators would not be affected by stress induced by pre-sampling handling (Voslářová et al. 2008). The heparinized blood was centrifuged at $837 \times g$ for $10 \mathrm{~min}$ and plasma samples were stored deep frozen $\left(-80{ }^{\circ} \mathrm{C}\right)$ in Eppendorf test-tubes until analyses were performed (till one week). Selected plasma biochemical 
indices: glucose, cholesterol, triglycerides, and total protein were measured by a Cobas EMira biochemical analyzer using commercial test kits (BioVendor - Laboratorni medicina a.s., CZ). Plasma corticosterone concentration was measured using commercial Corticosterone EIA Kit (Cayman Chemical, USA).

Tonic Immobility (TI) tests

A total of 40 birds: 10 birds per test group exposed to $80 \mathrm{~dB}$ (T80), 10 birds per test group exposed to $100 \mathrm{~dB}$ (T100), 10 birds per positive control group (T0) and 10 birds per control group of broilers (T) were used in testing for duration of TI. Each group of broilers consisted of 5 males and 5 females. Immediately following a 10 min noise exposure of each broiler in the test room (groups T80 and T100) and immediately following 10 min in the test room without noise exposure (group T0), birds were individually carried to a separate room and subjected to TI measurements according to a modified Benoff and Siegel (1976) procedure. TI tests were performed also in the control group of broilers. Tonic immobility was induced by laying the bird down on its right side and gently restraining it by hand for $15 \mathrm{~s}$. Then the hand was withdrawn and the experimenter retreated approximately $1 \mathrm{~m}$ and remained noiseless within the sight of the bird. The time was measured from withdrawal of the hand until the bird straightened up. When the bird straightened up in less than $10 \mathrm{~s}$, it was restrained repeatedly. When TI was not induced after three attempts, the duration of TI was considered $0 \mathrm{~s}$. When the bird did not straighten up within $10 \mathrm{~min}$, it was removed and given the maximal duration of $600 \mathrm{~s}$. The number of inductions required to attain TI was also recorded for each bird.

\section{Statistics}

Results were analysed using the statistical package Unistat 5.1. (Unistat Ltd., GB). Data with homogeneous variances (TI induction, triglycerides) were subjected to a one-way ANOVA and subsequently to a Tukey-HSD test (Zar 1999) for multiple comparisons in order to assess the statistical significance of differences between all possible pairs of groups. Data with heterogeneous variances (TI duration, corticosterone, cholesterol, total protein, glucose) were subjected to a Kruskal-Wallis ANOVA and subsequently to a non-parametric Tukey-type multiple comparisons test with ranked sums in order to assess differences between all possible pairs of groups (Zar 1999).

\section{Results}

The results of biochemical examinations of broiler chickens exposed to noise stimuli of $80 \mathrm{~dB}(80 \mathrm{~dB}, \mathrm{n}=10)$ or $100 \mathrm{~dB}(100 \mathrm{~dB}, \mathrm{n}=10)$ for $10 \mathrm{~min}$, positive control broilers $(\mathrm{PCON}, \mathrm{n}=10)$, and control broilers $(\mathrm{CON}, \mathrm{n}=10)$ are given in Table 1 .

Table 1. Selected biochemical indicators of broiler chickens exposed to noise stimuli of $80 \mathrm{~dB}(80 \mathrm{~dB}, \mathrm{n}=10)$ or $100 \mathrm{~dB}(100 \mathrm{~dB}, \mathrm{n}=10)$ for $10 \mathrm{~min}$, positive control broilers (PCON, $\mathrm{n}=10)$, and control broilers $(\mathrm{CON}, \mathrm{n}=$ $10)$ : Means \pm SEM (Standard Error of Mean) and significance of multiple comparisons tests.

\begin{tabular}{|l|c|c|c|c|}
\hline Indicator & CON & PCON & $80 \mathrm{~dB}$ & $100 \mathrm{~dB}$ \\
\hline $\begin{array}{l}\text { Corticosterone } \\
(\mathrm{ng} / \mathrm{ml})\end{array}$ & $0.41^{\mathrm{c}} \pm 0.07$ & $1.32^{\mathrm{b}, \mathrm{c}} \pm 0.34$ & $3.20^{\mathrm{a}, \mathrm{b}} \pm 0.69$ & $4.74^{\mathrm{a}} \pm 0.87$ \\
\hline $\begin{array}{l}\text { Triglycerides } \\
(\mathrm{mmol} / \mathrm{l})\end{array}$ & $0.86 \pm 0.10$ & $0.93 \pm 0.15$ & $0.63 \pm 0.08$ & $0.67 \pm 0.11$ \\
\hline $\begin{array}{l}\text { Cholesterol } \\
(\mathrm{mmol} / \mathrm{l})\end{array}$ & $3.54^{\mathrm{b}} \pm 0.06$ & $3.72^{\mathrm{a}, \mathrm{b}} \pm 0.20$ & $3.94^{\mathrm{a}, \mathrm{b}} \pm 0.13$ & $4.37^{\mathrm{a}} \pm 0.27$ \\
\hline $\begin{array}{l}\text { Glucose } \\
(\mathrm{mmol} / \mathrm{l})\end{array}$ & $14.54 \pm 0.17$ & $15.45 \pm 0.47$ & $14.84 \pm 0.32$ & $15.96 \pm 0.55$ \\
\hline $\begin{array}{l}\text { Total protein } \\
(\mathrm{g} / \mathrm{l})\end{array}$ & $34.87^{\mathrm{a}, \mathrm{b}} \pm 0.60$ & $32.97^{\mathrm{b}} \pm 1.11$ & $35.71^{\mathrm{a}, \mathrm{b}} \pm 1.25$ & $38.91^{\mathrm{a}} \pm 1.49$ \\
\hline
\end{tabular}

Means within a row lacking a common superscript ${ }^{\mathrm{a}, \mathrm{b}, \mathrm{c}}$ differ.

As follows from the results, no significant differences were found in any monitored variable between broilers that were transferred from their housing enclosure to the test room and underwent the collection of blood samples at 10-min intervals in the test room without noise treatment, and the control group of broilers from which blood samples were collected immediately after they had been captured in the enclosure. Noise stimuli of both $80 \mathrm{~dB}$ and $100 \mathrm{~dB}$ intensities for 10 min induced a highly significant $(p<0.01)$ elevation in plasma corticosterone level in broilers when compared with control broilers that were kept undisturbed for the entire preceding period. In addition, $100 \mathrm{~dB}$ broilers showed also 
a significant $(p<0.05)$ increase in corticosterone concentration when compared to the positive control broilers that were transferred to the test room only, and were not exposed to the noise stimuli. Broilers that were exposed to the noise stimuli of $100 \mathrm{~dB}$ exhibited a significant $(p<0.05)$ increase in the cholesterol level when compared to the control broilers, and a highly significant $(p<0.01)$ elevation in the total protein level when compared to the positive control broilers. Exposure of noise stimuli did not influence the glucose level and triglyceride concentrations in the blood of broiler chickens.

Examination of tonic immobility indices in broiler chickens exposed to noise stimuli of $80 \mathrm{~dB}(80 \mathrm{~dB}, \mathrm{n}=10)$ or $100 \mathrm{~dB}(100 \mathrm{~dB}, \mathrm{n}=10)$ for $10 \mathrm{~min}$, positive control broilers $(\mathrm{PCON}, \mathrm{n}=10)$, and control broilers $(\mathrm{CON}, \mathrm{n}=10)$ are given in Table 2 .

The results of TI tests showed

Table 2. Duration of tonic immobility (TI) and number of attempts to induce $\mathrm{TI}$ in broiler chickens exposed to noise stimuli of $80 \mathrm{~dB}$ $(80 \mathrm{~dB}, \mathrm{n}=10)$ or $100 \mathrm{~dB}(100 \mathrm{~dB}, \mathrm{n}=10)$ for $10 \mathrm{~min}$, in positive control broilers $(\mathrm{PCON}, \mathrm{n}=10)$, and control broilers $(\mathrm{CON}, \mathrm{n}=10)$ : Means \pm SEM (Standard Error of Mean) and significance of multiple comparisons tests.

\begin{tabular}{|l|c|c|}
\hline \multirow{2}{*}{ Group } & \multicolumn{2}{|c|}{ Tonic immobility } \\
\cline { 2 - 3 } & Duration (s) & Induction (attempts) \\
\hline CON & $89.60 \pm 40.99$ & $2.20^{\mathrm{a}} \pm 0.20$ \\
\hline PCON & $113.10 \pm 57.59$ & $2.00^{\mathrm{a}, \mathrm{b}} \pm 0.33$ \\
\hline $80 \mathrm{~dB}$ & $57.60 \pm 19.24$ & $1.70^{\mathrm{a}, \mathrm{b}} \pm 0.21$ \\
\hline $100 \mathrm{~dB}$ & $147.00 \pm 53.55$ & $1.20^{\mathrm{b}} \pm 0.13$ \\
\hline
\end{tabular}

Means within a column lacking a common superscript ${ }^{\mathrm{a}, \mathrm{b}}$ differ. a significant $(p<0.05)$ decrease in the number of attempts to induce tonic immobility in $100 \mathrm{~dB}$ broilers when compared to the control. Duration of tonic immobility was not affected by noise stimuli of any intensity monitored in our experiment.

\section{Discussion}

Although increasing emphasis has recently been put on ensuring the conditions of animal welfare and stress elimination during the fattening period and preslaughter processing of poultry, only minimal attention has been devoted to examining the impact of stress associated with noise exposure. Some studies focus on the effects of noise in poultry housing caused by ventilation fans and bird vocalizations (Stadelman 1958ab; McFarlane et al. 1989a; Campo et al. 2005; Miragliotta et al. 2006); other studies have monitored the effects of aircraft overflights (Hamm 1967; Book and Bradley 1990). Poultry is often exposed to acute noise levels before slaughter in slaughter houses where noise in the operational plant is caused predominantly by ventilation fans and operational machinery (slaughter line, operating carts, etc.). Although the current legislation requires that the noise level be minimised, the noise intensity to which poultry is exposed in slaughterhouses during slaughter is relatively high, varying in the range of $80-100 \mathrm{~dB}$ as seen in our observations. The negative impact of noise on animal welfare in slaughterhouses is also reported by Grandin (1996) and Geverink et al. (1998).

Our experiment simulated slaughterhouse sounds to which broilers were exposed for $10 \mathrm{~min}$ in the test room. Effects of acute noise exposure at two different levels were evaluated on the basis of examinations of selected biochemical plasma indicators and tonic immobility tests. Acute noise exposure showed a major impact on the levels of plasma corticosterone, which is an accepted indicator of stress condition in birds. Noise stimuli of both $80 \mathrm{~dB}$ and $100 \mathrm{~dB}$ intensities induced a highly significant elevation in the plasma corticosterone level in broilers when compared to the control birds. This is in agreement with Borg (1981) who found an increase in baseline steroid levels in white Leghorns exposed to noise. On the contrary, McFarlane and Curtis (1989) reported that continuous noise for seven days at the level 80 or $95 \mathrm{~dB}$ did not have a significant effect on the plasma corticosterone concentration of broiler chickens. Similarly, Stadelman (1958a) found no effect on growth when young chickens were exposed to noises of 80-118 dB. It appears that prolonged exposure to steady noise may lead to an adaptation to the given conditions and to a subsiding of the stress reaction which was very strong in our experiment of a 
sudden short-term increase in the level of noise. For the broilers subjected to the 10-min noise exposure, the level of plasma corticosterone increased several times in comparison to the control group of broilers. It increased from $0.41 \pm 0.07 \mathrm{ng} / \mathrm{ml}$ in control broilers to $3.20 \pm 0.69 \mathrm{ng} / \mathrm{ml}$ and $4.74 \pm 0.87 \mathrm{ng} / \mathrm{ml}$ in broilers exposed to noise of $80 \mathrm{~dB}$ and 100 $\mathrm{dB}$, respectively, whereas plasma corticosterone concentration in broilers that were placed in the test room and not exposed to noise was $1.32 \pm 0.34 \mathrm{ng} / \mathrm{ml}$. Stress response induced by exposure to a sound of $104 \mathrm{~dB}$ for $30 \mathrm{sec}$ was reported in chickens also by Gross (1990). The increased level of plasma corticosterone in broilers before slaughter is not only indicative of impaired welfare but it also has an impact on the quality of meat. An increase in corticosterone concentration is associated with a higher hue value, indicating that the meat becomes lighter and less red in colour. Thus, very high stress levels in broilers may cause the production of paler thigh meat (Kannan et al. 1997). A stress-induced increase in plasma cholesterol level is also undesirable with regard to the quality of meat.

Duration of tonic immobility was not affected by noise stimuli in our experiment. However, noise exposure at the $100 \mathrm{~dB}$ level decreased the number of attempts to induce tonic immobility in broilers. The opposite results were reported by Campo et al. (2005) in layers exposed to noise levels of $90 \mathrm{~dB}$ for $60 \mathrm{~min}$. They found significant differences in the tonic immobility duration but the number of inductions required to achieve the tonic immobility reaction did not differ between noise-treated and control hens. In both cases it can be concluded that the treated birds were more fearful than the control ones and that noise can be regarded as aversive.

In conclusion, a significant negative influence of noise exposure on the stress and fearfulness of broiler chickens was determined. The effect of different noise levels ( $80 \mathrm{~dB}$ vs. $100 \mathrm{~dB}$ ) was not significantly different, although the levels of all monitored biochemical indicators were higher in the group of broilers exposed to a higher level of noise $(100 \mathrm{~dB})$. With respect to the current increasingly strict requirements concerning the welfare of animals intended for slaughter, the negative impact of noise exposure in broilers before slaughter should be taken into account, and respective technological and organisational measures should be adopted.

\section{Stres u brojlerových kuřat v důsledku akutní expozice hluku}

Vliv akutního působení hluku byl sledován na skupině brojlerových kuřat ROSS 308 $(\mathrm{n}=80)$ ve věku 42 dní. V experimentu byl po dobu 10 min simulován hluk, kterému jsou brojleři vystaveni $\mathrm{v}$ praxi před porážkou na jatkách. Vliv akutního působení hluku o různé intenzitě $(80 \mathrm{~dB}$ a $100 \mathrm{~dB})$ byl hodnocen na základě biochemických ukazatelů krevní plazmy a testu tonické imobility. Expozice hluku na úrovni $80 \mathrm{~dB}$ i $100 \mathrm{~dB}$ vyvolala významné zvýšení plazmatické hladiny kortikosteronu. U brojlerů, kteří byli vystaveni vyšší intenzitě hluku $(100 \mathrm{~dB})$ došlo také ke zvýšení hladiny cholesterolu a celkového proteinu v plazmě. Hladina glukózy a triglyceridů v plazmě brojlerů nebyla působením hluku ovlivněna. Akutní expozice hluku neovlivnila délku tonické imobility, avšak u kuřat vystavených hluku o intenzitě 100 dB byl nutný nižší počet pokusů k jejímu navození.

\section{Acknowledgement}

Supported by the Research Project No MSM6215712402 Veterinary Aspects of Food Safety and Quality.

\section{References}

Agnes F, Sartorelli P, Abdi BH, Locatelli A 1990: Effect of transport loading or noise on blood biochemical variables in calves. Am J Vet Res 51: 1679-1681

Benoff FH, Siegel PB 1976: Genetic analyses of tonic immobility in young Japanese quail (Coturnix coturnix japonica). Anim Learn Behav 4: 160-162

Book CM, Bradley FA 1990: Behavioural effects of simulated F-4D aircraft overflights on Nicholas turkey poults. Poult Sci 69 (Suppl.): 22 
Borg E 1981: Physiological and pathogenic effects of sound. Acta OtoLaryngol (Suppl.) 381: 1-68

Campo JL, Gil MG, Davila SG 2005: Effects of specific noise and music stimuli on stress and fear levels of laying hens of several breeds. Appl Anim Behav Sci 91: 75-84

Council Directive 2007/43/EC laying down minimum rules for the protection of chickens kept for meat production. Off J Eur Union L 182: 19-25

De La Fuente J, Díaz MT, Ibáñez M, De Chavarri EG 2007: Physiological response of rabbits to heat, cold, noise and mixing in the context of transport. Anim Welf 16: 41-47

Forsling ML, Sharman DF, Stephens DB 1984: Vasopressin in the blood plasma of pigs and calves exposed to noise and vibration comparable with that experienced during transport. J Physiol 3: 57-96

Geverink NA, Bühnemann A, Van De Burgwal JA, Lambooij E, Blokhuis HJ, Wiegant VM 1998: Responses of slaughter pigs to transport and lairage sounds. Physiol Behav 63: 667-673

Grandin T 1996: Factors that impede animal movement at slaughter plants. JAVMA-J Am Vet Med Assoc 209: $757-759$

Gross WB 1990: Effect of exposure to a short-duration sound on the stress response of chickens. Avian Dis 34: 759-761

Hamm D 1967: Sensory stress effect on layers. Poult Sci 46: 1267

Kannan G, Heath JL, Wabeck CJ, Souza MC, Howe JC, Mench JA 1997: Effects of crating and transport on stress and meat quality characteristics in broilers. Poult Sci 76: 523-529

Kanitz E, Otten W, Tuchscherer M 2005: Central and peripheral effects of repeated noise stress on hypothalamicpituitary-adrenocortical axis in pigs. Livest Prod Sci 94: 213-224

Lanier JL, Grandin T, Green RD, Avery D, McGee K 2000: The relationship between reaction to sudden, intermittent movements and sounds and temperament. J Anim Sci 78: 1467-1474

Lazarević M, Žikić D, Ušćebrka G 2000: The influence of long term sound stress on the blood leukocyte count, heterophil/lymphocyte ratio and cutaneous basophil hypersensitive reaction to phytohemagglutinin in broiler chickens. Acta Vet-Beogr 50: 63-76

Maxwell MH 1993: Avian blood leukocyte responses to stress. Worlds Poult Sci J 49: 34-43

McFarlane JM, Curtis SE 1989: Multiple concurrent stressors in chicks 3. Effects on plasma-corticosterone and the heterophil-lymphocyte ratio. Poult Sci 68: 522-527

McFarlane JM, Curtis SE, Shanks RD, Carmer SG 1989a: Multiple concurrent stressors in chicks 1. Effect on weight gain, feed intake, and behavior. Poult Sci 68: 501-509

McFarlane JM, Curtis SE, Simon J, Izquierdo OA 1989b: Multiple concurrent stressors in chicks 2. Effects on hematologic, body composition, and pathologic traits. Poult Sci 68: 510-521

Miragliotta MY, Naas IA, Manzione RL, Nascimento FF 2006: Spatial analysis of stress conditions inside broiler house under tunnel ventilation. Sci Agric 63: 426-432

Otten W, KanitzE, Puppe B, Tuchscherer M, Brussow KP, Nurnberg G, Stabenow B 2004: Acute and long term effects of chronic intermittent noise stress on hypothalamic-pituitary-adrenocortical and sympathoadrenomedullary axis in pigs. Anim Sci 78 (Part 2): 271-283

Recommendation 1991: Recommendation No. R (91) 7 on the slaughter of animals. Council of Europe Recommendations, resolutions and declarations of the Committee of Ministers, pp.1-15

Schaffer D, Marquardt V, Marx G, Von Borell E 2001: Noise in animal housing - a review with emphasis on pig housing. Dtsch Tierarztl Wochenschr 108: 60-66

Stadelman WJ 1958a: The effects of sounds of varying intensity on hatchability of chicken egg. Poult Sci 37: 166-169

Stadelman WJ 1958b: Observations with growing chickens on the effects of sounds of varying intensities. Poult Sci 37: 776-779

Stephens DB, Bailey KJ, Sharman DF, Ingram DL 1985: An analysis of some behavioural effects of the vibration and noise components of transport in pigs. Q J Exp Physiol 70: 211-217

Talling JC, Waran NK, Wathes CM, Lines JA 1996: Behavioural and physiological responses of pigs to sound. Appl Anim Behav Sci 48: 187-201

Voslářová E, Chloupek P, Bedáňová I, Suchý P, Pištěková V, Večerek V 2008: The effect of pre-sampling handling time on blood plasma biochemical parameters of broilers. Dtsch Tierarztl Wochenschr 115: 62-65

Waynert DF, Stookey JM, Schwartzkopf-Genswein KS, Watts JM, Waltz CS 1999: The response of beef cattle to noise during handling. Appl Anim Behav Sci 62: 27-42

Zar JH 1999: Biostatistical Analysis. $4^{\text {th }}$ ed. Prentice Hall, Upper Saddle River, New Jersey, 663 p. 